\title{
BASIC STUDY OF COPYRIGHT FOR BATIK WOOD ARTISTS IN GUNUNG KIDUL, YOGYAKARTA
}

\author{
Slamet Subiyantoro; Susilaningsih; Dwi Maryono \\ Faculty of Teacher Training and Education, Universitas Sebelas Maret \\ E-mail: s.biyantoro@yahoo.co.id; susi_uns@yahoo.com; dwimarus@gmail.com
}

\begin{abstract}
The aims of this research is to explain the batik wood artists level of understanding of Copyright as part of Intellectual Property as stipulated in Act Number 19 Year 2002. The research was conducted with descriptive qualitative approach and the data were collected using questionnaires from 65 batik wood artists that were selected randomly from 673 artists in Gunung Kidul. The data is also completed with interviews from main informants, and observation results and content analysis results. The data validation was done use source triangulation techniques to obtain data that reflecting facts. Data analyzed with interactive model in cycle with stages data collection, data reduction, data presentation and data verification. The results show that the low implementation of copyright registration is not only due to the lack of artists in understanding the Copyright, but rather from the influence of socio - cultural aspects of society that are collective. Thus, emphasizing the moral aspect of the formal aspects such as Copyright that are part of the western culture. The Copyright Act Number 19 Number 2002 is the revision of previously Copyright Act which has not provided a proportional space for Moral Rights compared to Copyright which tends to the economic aspects.
\end{abstract}

\section{Key words : Intellectual Property, Copyright, Wood Craft Art, Moral Rights}

\section{A. INTRODUCTION}

Until today the attention and awareness of the Indonesian people on Intellectual Property especially the matter of Copyrights is still low. Although the benefits of Copyright are very significant in the aspect of legal protection of its creator related with economic implications. Lack of awareness of the legal protection of Copyright is found in the craftsmen community. Craftsmen only concerns on producing an art work and never demands more, such as if someone imitates the art work to earn personal gain (Riswandi and Syamsudin, 2004: 202).

Basically Copyright is a part of Intellectual Property which is derived from human creations that give birth to a right (Damian, 2004: 106 in Masdurohatun 2011: 51). That is the importance of Copyright that should be understood by the craftsmen because there is a right 
to art work which must be protected by an Act. While, the awareness of the importance of Copyright to the art work is still low among craftsmen, a continuous and sustainable socialization is necessarily needed. It is to guarantee a protection and legal certainty to the art work that is a valuable of intellectual work of its creators.

The ongoing process of non - protection of Copyright may encourage harmful piracy behavior on certain parties. The Copyright piracy can undermine the social, economic, and legal for the Indonesian. Referring to Indonesian Act Number 19 Year 2002 regarding Copyright is actually intended to protect the Copyright and to encourage greater passion and interest to create multiple art work for its craftsmen and others (Masdurohatun 2011: 51).

But, sometime there are violations of Copyright in the implementation of the provisions in its Act. According to the reports from professional associations related to Copyright, such as: films, books, music, that Copyright piracy is still happening and even widespread. It is reaching in a critical condition and even reduces creativity that can lower community life in the widest - extent (Masdurohatun 2011: 51).

The issues of Intellectual Property especially Copyright is an interesting theme to investigate. Several researches related to Intellectual Property have been conducted by experts as follows. The research about Intellectual Property conducted by Mashdurohatun (2011) focuses on problems of Copyright in the Indonesia. While Hapsari (2012) discusses on the existence of Moral Rights in Copyright in Indonesia. This issue is interesting because Copyright and Moral Rights is paradoxical.

Research about comparative Copyright has been done by Prabandari (2011) which discusses the comparison of Copyright arrangements in Indonesia and the United States. A comparative research also done by Dharmawan (2010) which is more specific discusses legal protection for computer programs work in Indonesia as a developing country and with a legal protection for computer programs work in developed countries.

Research about Intellectual Property protection related to the potential of the natural wealth heritage has been discussed by Rofikah, Imanullah, Zultan (2006) which focuses on the protection of Intellectual Property on medicinal plants varieties that are abundant in Mount Lawu District Tawangmangu, Karanganyar Regency. Another research related to Intellectual Property which is collective is done by Hadi (2008) which is focuses on geography indication as a form of communal Intellectual Property. The other case research is 
conducted by Lestari (2013), which discusses the Copyright ownership in the license agreement towards the Supreme Court Decision Number: 104 PK/PDT.SUS/2011.

Some of the studies and researches above though quite diverse unfortunately not a single research that empirically discussed on the basic understanding of batik wood craftsmen towards Copyright. The limited knowledge of craftsmen about Intellectual Property is caused by the lack of socialization about Intellectual Property, which is why craftsmen have low awareness and commitment towards Copyright. From the research background above, the research problems can be formulated as follows: How far the craftsmen understanding towards Copyright and its implementation in registering the art work/ product Copyright as Intellectual Property.

\section{B. PROBLEM STATEMENTS}

The research objective is to find out the knowledge level of craftsmen towards Copyright and its implementation in registering the art work/ product Copyright as Intellectual Property.

It is hoped that this research can be useful theoretically to increase or broaden the knowledge about Intellectual Property for craftsmen. Practically, it can be an suggestion for local government or central, to make policy and socialization for craftsmen about the awareness of Copyright protection.

\section{LITERATURE REVIEW}

Copyright has its own characteristics compared to the Intellectual Property; Copyright automatically exists after the product is created without having to be registered. The function of registering the creation is not to issue Copyright but only to raises the presumption that the person registering the product is the creator and the Copyright holder (Lestari, 2013: 187).

Intellectual Property should be considered as a creation of thought in the technology, trade, and art (Media KI (b1), 2015: 25). Intellectual Property issues are closely related and can not be separated from creative economy business and franchise (Media KI (b2), 2015: 29). In fact, the arrangement of economic rights tends to be more prominent than Moral Right which is very limited and merely seems to adopt the auteurswet provision (Hapsari 1912: 462). 
Act Number 19 Year 2002 about Copyright contains two important basic concepts that are Exclusive Rights and right that arise automatically. Those concepts have consequences for the emergence of legal protection for personal work. This personal characters issues Moral Right associated with its personal creator's. The fulfillment of Moral Rights is important because a product is issued form the creators sacrifices' so that intergrity and identity are indispensable towards Copyright protection (Hapsari, 1912; 464).

The emergence of Copyright Act Year 2014 is the government's effort to protect the economic right and moral right of the craftsmen in the creative industry. It is meant to encourage to be active in production and creativity to create art works that can improve the country's economy to face ASEAN Economic Community (AEC) 2015. Through the Copyright protection of creative industry in Indonesia, it can be on of the economic strengths to keep growing and contributes for Indonesian's economy (Media KI (a), 2015: 24).

\section{THEORETICAL FRAMEWORK}

Indonesian is consist of different races, tries, religions, and beliefs although have a mutual sense as a collective society. Javanese is one of the dominant ethnics in terms of art and culture. Javanese people is known of its delicate culture, harmony, and sublime and often referred as the representation of eastern culture.

Javanese people are mostly created an art work which medium is from wood. Some of them that have been made in Gunung Kidul are masks, various animal replicate, loro blonyo statue, menongan dolls, tissue box, water dispenser, a box/ plate for displaying/ store fruits, and various kinds toys made from wood. The above products are the representation of the craftsmen's creativity which represents craftsmen collective society.

To manifest the art works from the above idea, it can not be separated from the Intellectual Property which is integrated in knowledge system, behavior, and the results. The process and result of the Indonesia art works that were done collaboratively are representing the Moral Rights. Meanwhile, an individual art work tends to represent western culture. Copyright Act as stated in Act Numbet 19 Year 2002 is lean to individual Copyright rather than collaborative art works toward Moral Rights. 


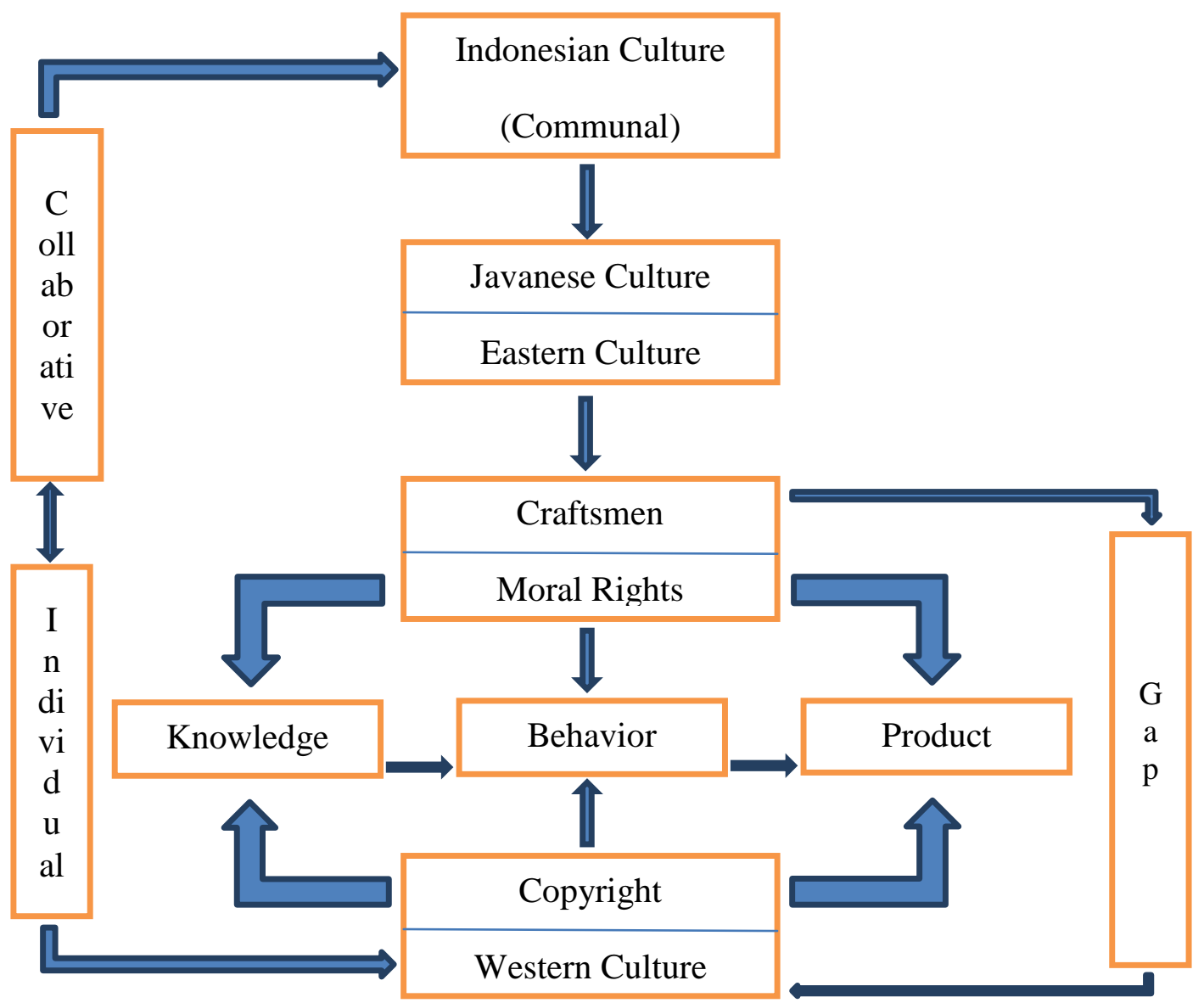

\section{E. RESEARCH METHOD}

This research employs descriptive qualitative approach - single case study embedded (Bogdan, dan Taylor, 1993: 56). The location of the research is in central wood craft in Bobung village Gunung Kidul, Yogyakarta. 65 craftsmen are chosen as respondent to find out how far the craftsmen understanding towards Copyright and its application in registering Intellectual Property. They represent craftsmen, who made wooden mask, loro blonyo statue, souvenirs, animal replicate from wood, and other such as tissue box, water dispenser, menongan dolls, and wooden toys.

Respondents are chosen using random sampling, while the informants are chosen using purposive sampling. The informants are selected according to the research objectives as to why in accordance having same characteristic as craftsmen associated with the understanding and implementation in registering Copyrights. The primary data were collected using open 
and closed questionnaires. Closed questionnaires are equipped with statement and optional answer and the respondent only need to give cross mark on the answer. The primary data also completed with deep interview focuses on key/ main informant of craftsmen (Spreadley, 1979: 10). The data also collected using passive intimate observation as to preserve the situation while keep it as it is (Spreadley, 1980). In completing the data it is also used documents/ legal archive in forms of An Act in correspondence of Copyright Act. The other sources are journals, books, research reports discussing legal protection.

To present the data validation, the researchers uses triangulation source technique (Nasution, 1988). Furthermore, the data are analyzed using interactive cycle models which through data collection, data reduction, data presentation, and data verification.

\section{F. RESEACRH RESULTS AND DISCUSSIONS}

\section{Research Results}

The results of the questionnaires shows that $38.5 \%$ craftsmen in general already attended the socialization about Intellectual Property but they do not understand what is meant. There are $23.3 \%$ craftsmen who do not know about the concept of Intellectual Property. Even 10\% craftsmen just heard about Intellectual Property, while only 9\% craftsmen that already knew about Intellectual Property. It confirms that the craftsmen understanding toward Intellectual Property is very low. In addition, there is an impression that the concept and Intellectual Property existence are considered as knowledge that difficult to understand in the cultural context of craftsmen which is belongs to Javanese communal communities.

Table 1. Data about craftsmen understanding towards Intellectual Property

\begin{tabular}{lll}
\hline Do you know the concept of Intellectual Property? & Total & \multicolumn{1}{c}{$\begin{array}{c}\text { Percentage } \\
(\%)\end{array}$} \\
\hline Do not know & 21 & $32,3 \%$ \\
Attending socialization but do not what it means & 25 & $38,5 \%$ \\
Just heard 'Intellectual Property' & 10 & $15,4 \%$ \\
Already know & 9 & $13,8 \%$ \\
Total & 65 & $100 \%$ \\
\hline
\end{tabular}


Source : primary data

Nevertheless, the data shows $60 \%$ of the averages craftsmen already understand about Copyright. While, 29.2\% craftsmen claimed have attended the socialization of Copyright but still do not get the idea. Furthermore only $6 \%$ of craftsmen do not know about the Copyright. And $1 \%$ craftsmen just heard the terms of Copyright. It is the opposite from the data because craftsmen are better informed and understand about Copyright rather Intellectual Property. It is logic, because Copyright is just one of several types of Intellectual Property such as Patent Rights, Industrial Design Rights, and Trade Mark Rights, etc.

Tabel 2. Data about craftsmen understanding about Copyright

\begin{tabular}{lll}
\hline Do you know about Copyright ? & $\begin{array}{l}\text { Total } \\
\text { Do not know }\end{array}$ & $\begin{array}{c}\text { Percentage } \\
(\%)\end{array}$ \\
Attending socialization but do not the what it means & 6 & $9,3 \%$ \\
Just heard & 19 & $29,2 \%$ \\
Already know & 1 & $1,5 \%$ \\
Total & 39 & $60 \%$ \\
\hline
\end{tabular}

Source : primary data

$75.4 \%$ craftsmen mostly agreed that Copyright is important and necessarily needed to protect the Copyright. However, $21.1 \%$ craftsmen say it is important though they do not the use of Copyright. And 3.5\% craftsmen say that Copyright is no use because they do not know yet the use of it. This data proves that Copyright is something important to be considered for craftsmen especially to protect their Copyrights.

Table 3. Data about the means of Copyright for craftsmen

\begin{tabular}{lll}
\hline Do you consider that Copyright is something important? & $\begin{array}{c}\text { Total } \\
\text { Not important }\end{array}$ & $\begin{array}{c}\text { Percentage } \\
(\%)\end{array}$ \\
Important whether do not know the use of it & - & - \\
Important to protect their Copyright & 43 & $21,1 \%$ \\
Not important because do not know the use of it & 2 & $3,5 \%$ \\
Total & 57 & $100 \%$
\end{tabular}


Source : primary data

In accordance with Copyright, mostly $31.3 \%$ craftsmen do not feel disadvantaged if his/her works imitated by the others. Even, $22.4 \%$ craftsmen feel happy if their works were imitated because they feel that their works are recognized by the others. It means that $53.7 \%$ craftsmen do not questioning about the Copyright. Nevertheless, there are $28.4 \%$ craftsmen will demand compensation if their works imitated and the rest $17.9 \%$ craftsmen will even file a report to the authorities. This means that there $46.3 \%$ craftsmen questioned about the imitation of their works. Nevertheless, the data above shows that the average craftsmen prefer not to make dispute over their works that were being imitated by the others compared with the other craftsmen who make such a fuss over it.

Table 4. Craftsmen who do not care if their works were imitated

\begin{tabular}{llc}
\hline $\begin{array}{l}\text { What do you think if your works were imitated by the } \\
\text { other craftsmen }\end{array}$ & $\begin{array}{c}\text { Total } \\
\text { Not a big deal }\end{array}$ & $\begin{array}{c}\text { Percentage } \\
(\%)\end{array}$ \\
Happy (recognized by the others) & 15 & $31,3 \%$ \\
File a report to the authorities & 12 & $22,4 \%$ \\
Demand compensation & 19 & $28,4 \%$ \\
Total & 67 & $100 \%$ \\
\hline
\end{tabular}

Source : primary data

There $28.8 \%$ craftsmen feel happy if the Copyright their works is registered by the other craftsmen. It is because they feel that their works has been acknowledged by the others and it is represented by total of $24.2 \%$ craftsmen agreed about that. Thus, $53 \%$ craftsmen who do not questioning if the others craftsmen imitates and registering the Copyright of their work as the work of the registrants. Nevertheless, there $47 \%$ craftsmen who questioning if their work being imitated and registered the Copyright with the name of the imitators. There are $24.2 \%$ craftsmen who will file a report to the authorities if their work is imitates and claimed the Copyright. While, $22.8 \%$ craftsmen will demand compensation to the imitators who registered the Copyright. The above percentage shows that the craftsmen who do not questioning the imitating and Copyright is bigger than the other who make dispute over it. This means that the craftsmen give permission to the other craftsmen to claim and even register the Copyright as the imitator Intellectual Property. 
Table 5. data about work which claimed and registered by the other craftsmen

\begin{tabular}{llc}
\hline $\begin{array}{l}\text { What do you think if your works is claimed and registered by } \\
\text { the others }\end{array}$ & $\begin{array}{c}\text { Total } \\
\text { Not a big deal }\end{array}$ & $\begin{array}{c}\text { Percentage } \\
(\%)\end{array}$ \\
Happy (being recognized) & 16 & $24,2 \%$ \\
File a report to the authorities & 19 & $28,8 \%$ \\
Demand compensation & 16 & $24,2 \%$ \\
Total & 15 & $22,8 \%$ \\
\hline
\end{tabular}

Source : primary data

So far, among the respondent there are who already registered their Copyright in the Ministry of Law and Human Rights. There are 4 respondents or $6.1 \%$ who have registered the Copyright more than three times as much as $4.5 \%$ respondent because they were funded by the others. However, there are $89.4 \%$ respondents stated that they never registered their works to the Ministry of Law and Human Rights. It can be concluded that most of craftsmen have not applied their understanding about Copyright.

Table 6. data about experience in registering Copyright

\begin{tabular}{lcc}
\hline $\begin{array}{l}\text { How many times have you registering your works as your } \\
\text { Intellectual Property }\end{array}$ & $\begin{array}{c}\text { Total } \\
(\%)\end{array}$ \\
\hline Once & - & - \\
More than 3 times & 4 & $6,1 \%$ \\
Never & 59 & $89,4 \%$ \\
Sponsored by the others & 3 & $4,5 \%$ \\
Total & 66 & $100 \%$ \\
\hline
\end{tabular}

Source : primary data

The data shows that $78.1 \%$ respondent claimed that they have attended socialization about Intellectual Property. $18.8 \%$ respondents claimed that they have once attended the socialization of Intellectual Property. Moreover, 3.1\% respondents stated that they have attended such socialization twice. It means that $21.9 \%$ respondents have attended the socialization about Intellectual Property. Nevertheless, the data above shows that craftsmen who have not attending such socialization are bigger than who have attending the socialization. 
Table 7. data about attending the socialization of Intellectual Property

\begin{tabular}{lcc}
\hline $\begin{array}{l}\text { How many time have you attend the socialization about } \\
\text { Intellectual Property }\end{array}$ & $\begin{array}{c}\text { Total } \\
\text { Percentage } \\
(\%)\end{array}$ \\
\hline Never & 50 & $78,1 \%$ \\
Once & 12 & $18,8 \%$ \\
Twice (2) & 2 & $3,1 \%$ \\
Three (3) times & - & - \\
Total & 64 & $100 \%$ \\
\hline
\end{tabular}

Source : primary data

$57.1 \%$ respondents are not willing in registering their Copyright of their works. The reason behind craftsmen who are not willing in registering the Copyright is caused by: (1) do not know the use of it, (2) the long terms benefits, (3) the process take a time, (4) do not know how to do it, (5) the cost is expensive, better for the other needs, (6) less important, and (7) less preeminent works.

There are $42.9 \%$ respondents' wants to register their Copyright. It cause by: (1) improving their business, (2) protecting their art works, (3) to be recognized, (4) product status, (5) protecting the identity, (6) preventing the imitations, and (7) long terms benefits.

From the data above shows that craftsmen who are not willing in registering their Copyright are bigger than the others. It means that the craftsmen awareness in protecting their Copyright to preventing the imitations and misused by the others is low.

Table 8. the craftsmen willingness in registering their Copyright

\begin{tabular}{lcc}
\hline Do you want to register your Copyrights & Total & $\begin{array}{c}\text { Percentage } \\
(\%)\end{array}$ \\
\hline No & 32 & $57,1 \%$ \\
Yes & 24 & $42,9 \%$ \\
Total & 56 & $100 \%$ \\
\hline
\end{tabular}

Source : primary data

$66.7 \%$ respondents aware that violating Copyright will bring harm for the society but can do anything about it. While, $18.2 \%$ respondents are fully aware that Copyright violations will bring harm for the existence. The data shows that $84.9 \%$ respondents already knew the 
effect of Copyright violations is harmful. $18.2 \%$ respondents are half aware and $6.1 \%$ respondents who know nothing about the violation of Copyrights. It can be concluded that mostly respondents already the effect of violating the Copyrights.

Table 9. data of awareness level of violating Copyrights in society

\begin{tabular}{lll}
\hline $\begin{array}{l}\text { Do you know that violating Copyright will bring harm for } \\
\text { the society? }\end{array}$ & $\begin{array}{c}\text { Total } \\
\text { Do not know }\end{array}$ & $\begin{array}{c}\text { Percentage } \\
(\%)\end{array}$ \\
\hline Conscious but can not do anything & 4 & $6,1 \%$ \\
Fully aware & 44 & $66,7 \%$ \\
Half aware & 12 & $18,2 \%$ \\
Total & 6 & $9,1 \%$ \\
\hline
\end{tabular}

Sumber : data primer

49.2\% respondents aware and know about the impact of Copyright infringement may come at the legal domain but they can not do anything about it. 32.3\% respondents are fully aware that Copyright infringement may lead to legal affairs. While, $10.8 \%$ respondents are half aware about the consequences of Copyright infringement will bring legal sanction and 7.7\% know nothing about it. It means that mostly craftsmen/ respondents already knew the consequences of Copyright infringement will bring fatal impact in legal affairs.

Table 10. awareness level about the effect of violating Copyrights toward legal aspect

\begin{tabular}{lll}
\hline $\begin{array}{l}\text { Do you know that Copyright infringement will bring legal } \\
\text { affairs }\end{array}$ & $\begin{array}{c}\text { Total } \\
\text { Do not know }\end{array}$ & $\begin{array}{c}\text { Percentage } \\
(\boldsymbol{\%})\end{array}$ \\
Aware but can do anything & $\mathbf{5}$ & $7,7 \%$ \\
Fully aware & 32 & $49,2 \%$ \\
Half aware & 21 & $32,3 \%$ \\
Total & 7 & $10,8 \%$ \\
\hline
\end{tabular}

Source : primary data

Mostly respondents/ craftsmen are fully aware about Copyright infringement will effecting on economic affairs. 58.5\% respondents are fully aware that Copyrights infringement will affect the economy and $26.1 \%$ respondents are aware of it but can do 
anything about it. $7.7 \%$ respondents are half aware and half understood about it. While, the other $7.7 \%$ respondents do not know that Copyrights infringement will cause a fuss on economic affairs. Thus, mostly respondents total $84.6 \%$ are aware about Copyrights infringement will affect economic affairs.

Table 11. awareness of Copyrights infringement toward economy affairs

\begin{tabular}{lll}
\hline $\begin{array}{l}\text { Do you realize the Copyrights infringement will bring an } \\
\text { implications on economy affairs }\end{array}$ & $\begin{array}{c}\text { Total } \\
\text { Percentage } \\
(\%)\end{array}$ & $7,7 \%$ \\
\hline Do not know & 5 & $26,1 \%$ \\
Fully aware but can do anything & 17 & $58,5 \%$ \\
Half aware & 38 & $7,7 \%$ \\
Total & 5 & $100 \%$ \\
\hline
\end{tabular}

Source : Primary data

\section{Discussions}

The data of the research shows that the craftsman understanding towards Intellectual Property is only $9 \%$ it means that the understanding is very low. It can be caused that $78.1 \%$ craftsmen/ respondents have not attending socialization about Intellectual Property and such. However, craftsmen understanding about Copyrights are high enough on 60\%. It closely related with $75.4 \%$ respondent who stated that Copyrights is an important and they can feel the benefits on legal protection.

But, the fact shows that many of craftsmen have not registered their Copyright. The data shows that $89.4 \%$ respondent have not been registered their Copyrights. Furthermore, only $4.5 \%$ respondent stated that they have been registered their Copyright because it was funded by the others parties. As in fact there are $57.1 \%$ respondents who do not want registering their Copyrights. That is why $53.7 \%$ respondents' do not questioning if their art works were imitates by the other craftsmen. It is even stranger that 53\% respondent allows if their art works were claimed and registered its Copyright as in the name of registrants.

Actually craftsmen already knew the effect of Copyrights infringements will bring harms on social, economy and legal aspect in society. $81.5 \%$ craftsmen aware and knew that Copyrights infringements will affect on legal affairs and $84.6 \%$ respondent aware that it will bring an implication on economy aspects. 
The issues about Copyrights which is allowed to be imitated and claimed by the other craftsmen in Gunung Kidul is no different from the findings of Riswandi and Syamsudin (2004: 202) in Boyolali. The difference is only on object of research, in Boyolali the object is copper brass handicrafts while in Gunung Kidul is crafts made from batik wood. Copper craftsmen do not make a fuss if the style and model they have created are imitated by the others. Nor do they charge the imitators to the judiciary even if they are aware that they were not being benefited economically. However, on this research taken on Gunung Kidul there are craftsmen who demand compensation and file a report to the authorities if there is a violation, but there are only in small number.

This reverse reality shows that there are craftsmen who knew about the impact of Copyrights infringement and on the other side the loosen awareness craftsmen towards this piracy shows that they can do anything. It is related to the context of customary in Indonesian that accidentally loose to create stability and harmony in society. Boyolali and Gunung Kidul belongs to Central Java which is still preserved the strong collaborates.

That is why Indonesian people with no exception in Gunung Kidul and Boyolali actually do not know about the Copyrights. It is a basic concept that brings a dilemma in law enforcement of Copyrights because Copyrights is not rooted in our culture. Public still considers that a Copyrights is a joint ownership while and Act regards Copyrights as an individual ownership. This difference is one of the uncontrolled Copyrights infringements in Indonesia (Masdurohatun 2011: 54).

The differences in point of view brings the consequences of an act is a piracy towards Copyrights from an Act of Copyrights point of view, however on the society point of view this piracy is not crime that should be punished. Indonesian point of view is based on society law customary which sees togetherness with share property rights. An example of an artist which his works is imitated will not make such a fuss rather feel proud and considered the imitators as his students or followers. The study of differences in point of views bring an effect is already belongs to a copyrights according to the Act of Copyrights, but the society sees that as a crime that no need a punishment (Masdurohatun, 2011: 51 - 54). It is where the existence of exclusive rights that have not been comparable among moral rights based on indidenous Indonesian communal personality with Copyrights based on individuality leans to western culture that tends on the economic aspects. 


\section{F. CLOSING}

\section{Conclusion}

The conclusion of this research shows that the low implementation craftsmen in registering Copyrights and loosen toward possibility of Copyrights infringements which affect legal nor economy affairs is not only because of the lack information about Copyrights. The cultural aspects of craftsmen give greater influence especially in upholding the collaborative value about an art work is not an individual copyrighted property. It is consequently ignoring the legal aspect that was arranged on Act Number 19 Year 2002 regarding Copyrights. The communal aspect implies on social characters rather on individual who pursing economy solely. Act Number 19 Year 2002 regarding Copyrights is a revision of Act Number 7 Year 1987 still has not discussing about how moral rights can be accommodate and it is tends to economy aspect which is inappropriate with Indonesian personality.

\section{Suggestions}

1. Local government needs to socialize and accommodate the craftsmen in giving an understanding about Intellectual Property such as Copyrights.

2. The nearest university should cooperatively work with craftsmen creating their copyrighted art work legally, as to fulfill the needs of an era globally.

\section{F. GRATITUDE}

This gratitude is meant for Director of Research and Community Services in Ministry of Research, Technology and Higher Education that has funded this research activity in Community Service for Featured Area on first year (2017).

\section{BIBLIOGRAPHY:}

\section{Books and Journals:}

Bogdan, R dan Taylor, S, 1993, Kualitatif : Dasar-Dasar Penelitian (terjemahan Afandi, A.K). Surabaya: Usaha Nasional

Dharmawan, N.K.S, 2011, "Perlindungan Hukum Atas Karya Cipta Program Komputer Di Indonesia (Studi Perbandingan Dengan Negara Maju dan Negara Berkembang)”. Fakultas Hukum Universitas Diponegoro Semarang: Jurnal Masalah-masalah Hukum. Volume 40, Number1. 
Hadi, H, 2008, “Indikasi Geografis Sebagai Bentuk Hak Kekayaan Intelektual Yang Bersifat Komunalistik”. Yustisia. Jurnal Hukum. Edition 73.

Hapsari, F.T, 2012, “Eksistensi Hak Moral Dalam Hak Cipta Di Indonesia. Fakultas Hukum Universitas Diponegoro Semarang: Jurnal Masalah-masalah Hukum”. Volume 41, Number 3

Lestari, H.D. 2013. “Kepemilikan Hak Cipta Dalam Perjanjian Lisensi”. Jurnal Yudisial: Hak Dalam Kemelut Hukum. Volume. 6, Number 2.

Mashdurohatun, A. 2011. "Problematika Perlindungan Hak Cipta di Indonesia". Yustisia Jurnal Hukum. Edisi 82 Th XXII.

Media HKI.2015 (a). "Perlindungan Hak Cipta untuk Pengembangan Ekonomi Kreatif”. Tantangan Implementasi Patent Prosecution Highway (PPH) di Indonesia. Volume XII, Number 5.

Media HKI.2015 (b1). “Serba Serbi HKI”. Media HKI Peran Kekayaan Intelektual dalam Pengembangan Waralaa dan Ekonomi Kreatif. Volume XII, Number 6.

Media HKI.2015 (b2). "Bekasi Education Fair 2015 di Bekasi Town Square (Betos)”. Media HKI Peran Kekayaan Intelektual dalam Pengembangan Waralaa dan Ekonomi Kreatif. Volume XII, Number 6.

Nasution. 1998. Penelitian Kualitatif Naturalistik. Bandung: Tarsito

Prabandari, AP. 2013. “Komparasi Pengaturan Hak Cipta Di Indonesia Dan Amerika Serikat. Fakultas Hukum Universitas Diponegoro Semarang”: Jurnal Masalah-masalah Hukum. Volume. 42, Number 2.

Riswandi, B.A. \& Syamsudin, M. 2004. Hak Kekayaan Intelektual dan Budaya Hukum. Jakarta: PT Raja Grafindo

Rofikah, Imanullah, M.N. dan Zultan, R. 2006. "Perlindungan Hak Kekayaan Intelektual (HKI) Varietas Tanaman Obat Di Gunung Lawu Wilayah Kecamatan Tawangmangu Kabupaten Karanganyar”. Jurnal Hukum: Yustisia. Edition 72.

Spradley, J.P. 1979. The Ethnographic Interview. New York: Holt, Rinehart and Winstons Spradley 1980. Participant Observation. New York: Holt, Rinehart and Winstons 


\section{Regulation:}

Law Number 19 of 2002 On The Copyrights. 